\title{
Evaluation of the performance of titanium and zirconium salts as coagulants in industrial wastewater treatment: pollutant removal, sludge production, and sludge characteristics
}

\author{
Ayla Uysal $^{1}$ (D) . Eda Boyacioglu ${ }^{1}$ (D)
}

Received: 30 December 2020 / Accepted: 3 April 2021 / Published online: 19 April 2021

(c) The Author(s) 2021

\begin{abstract}
In this study, titanium tetrachloride $\left(\mathrm{TiCl}_{4}\right)$, zirconium tetrachloride $\left(\mathrm{ZrCl}_{4}\right)$, and zirconium oxychloride $\left(\mathrm{ZrOCl}_{2} \cdot 8 \mathrm{H}_{2} \mathrm{O}\right)$ were evaluated using jar test experiments as coagulants and compared with traditional aluminum sulfate $\left(\mathrm{Al}_{2}\left(\mathrm{SO}_{4}\right)_{3} \cdot 18 \mathrm{H}_{2} \mathrm{O}\right)$ and ferric chloride $\left(\mathrm{FeCl}_{3}\right)$ for industrial wastewater treatment. The effects of the initial $\mathrm{pH}$ of $4-10$ and initial coagulant doses of 10-100 mg/L on chemical oxygen demand (COD) and total suspended solids (TSS) removal were investigated. The performances of the five coagulants were also assessed in terms of the settled sludge volume, the sludge volume index (SVI), and removal efficiencies of metals, color, and total phosphorus (TP) under optimum conditions. In addition, the contents of the residual sludge produced for all five tested coagulants under optimum conditions were determined. The results showed that the maximum removal efficiency of COD (69.33\%) was achieved using $100 \mathrm{mg} / \mathrm{L} \mathrm{TiCl}{ }_{4}$ at $\mathrm{pH} 8$. The maximum removal efficiency of TSS $\left(98.32 \%\right.$ ) was achieved using $50 \mathrm{mg} / \mathrm{L} \mathrm{Al}_{2}\left(\mathrm{SO}_{4}\right)_{3} \cdot 18 \mathrm{H}_{2} \mathrm{O}$ at both pH 8 and 10 . The settled sludge volume and SVI generated by $\mathrm{TiCl}_{4}$ were lower than that for the other four tested coagulants. $\mathrm{ZrCl}_{4}, \mathrm{ZrOCl}_{2} \cdot 8 \mathrm{H}_{2} \mathrm{O}, \mathrm{FeCl}_{3}$, and $\mathrm{Al}_{2}\left(\mathrm{SO}_{4}\right)_{3} \cdot 18 \mathrm{H}_{2} \mathrm{O}$ resulted in $128.13,92.39,72.26$, and $69.66 \mathrm{~mL} / \mathrm{g} \mathrm{SVI}$, while that using $\mathrm{TiCl}_{4}$ was $48.84 \mathrm{~mL} / \mathrm{g}$. Ti- and $\mathrm{Zr}$-based coagulants achieved better removal efficiencies of TP, $\mathrm{Zn}$, and $\mathrm{Cu}$ than $\mathrm{FeCl}_{3}$ and $\mathrm{Al}\left(\mathrm{SO}_{4}\right)_{3} \cdot 18 \mathrm{H}_{2} \mathrm{O}$. The residual sludge from using Ti and $\mathrm{Zr}$ coagulants had a very high TP content. The results indicated that Ti- and Zr-based coagulants could be used as alternatives to traditional coagulants for industrial wastewater treatment.
\end{abstract}

Keywords Coagulation · Industrial wastewater treatment · Residual sludge · Sludge volume index · Titanium salt · Zirconium salt

\section{Introduction}

Industrial wastewater treatments vary according to the characteristics of the wastewater. Some industries' wastewater can be decomposed biologically, while others might contain nonbiodegradable constituents. Industrial wastewater treatment plants generally use chemical treatment technologies. These technologies might be a stand-alone or pretreatment process before the consecutive biological treatment phases.

Ayla Uysal

aylauysal@sdu.edu.tr

Eda Boyacioglu

celikeleda@gmail.com

1 Department of Environmental Engineering, Suleyman Demirel University, 32260 Isparta, Turkey
Coagulation-flocculation processes are the most commonly used chemical treatments for removing pollutants, such as biochemical oxygen demand (BOD), chemical oxygen demand (COD), total suspended solids (TSS), heavy metals, and color in industrial wastewater before other treatment methods are used (Jarvis et al. 2005; Syafalni et al. 2012; Galloux et al. 2015). Aluminum sulfate $\left(\mathrm{Al}_{2}\left(\mathrm{SO}_{4}\right)_{3}\right)$, ferric chloride $\left(\mathrm{FeCl}_{3}\right)$, and polyaluminum chloride are widely used as coagulants because they have demonstrated a high affinity for removing a wide range of pollutants found in wastewater (Zhao et al. 2011a; Galloux et al. 2015). However, the coagulation-flocculation treatment methods involve these chemicals as the treating agents, which could constitute a potential risk to the quality of the environment itself and cause the generation of excess sludge during the coagulation-flocculation treatment process (Tatsi et al. 2003; Syafalni et al. 2012). Most of this sludge is solid waste from which nothing 
can be recovered or reused, and that then requires further treatment, such as incineration and disposal into a landfill (Shon et al. 2007). Disposal of chemical sludge into the landfill is not an acceptable method because it can cause secondary pollution, such as landfill leachate and soil contamination (Zhao et al. 2011a). Thus, it is important to apply the appropriate coagulant in the coagulation-flocculation process to overcome these potential disadvantages and increase the efficient application of an alternative treatment. A coagulant that produces less sludge or more reusable sludge offers a better solution to many environmental and economic problems associated with sludge handling (Okour et al. 2009).

In recent years, various new coagulants have been studied and developed, such as organic, inorganic, and composite coagulants. Titanium (Ti) salt, as an inorganic coagulant, is an attractive alternative to inorganic metal coagulants. Ti salt used in the coagulation of wastewater shows a high flocculation performance of turbidity and organic removal (Okour and Ahmed 2019). Recent investigations have demonstrated the strong flocs-forming properties of zirconium oxychloride $\left(\mathrm{ZrOCl}_{2} \cdot 8 \mathrm{H}_{2} \mathrm{O}\right)$. This new coagulant has shown pronounced effects on water clarification (Priya et al. 2017). $\mathrm{Ti}$ and its compounds have been reported to be minimally toxic and are rarely included in any water quality guidelines (Wu et al. 2011). Similarly, it has been reported that zirconium $(\mathrm{Zr})$ is generally believed to be nontoxic as an element or in compounds (Jarvis et al. 2012; Hussain et al. 2014). However, research on the use of Ti and/or Zr salts as coagulants to treat pollutants was conducted mainly for surface water treatment. A few other studies examined these metals salts for treatment of synthetic wastewater (Shon et al. 2007; Okour et al. 2009; Okour and Ahmed 2019). To the best of our knowledge, however, few studies on treatment of real wastewater by $\mathrm{Ti}$ and/or $\mathrm{Zr}$ salts have been reported (Galloux et al. 2015; Pushpalatha and Lokeshappa 2015; Aziz et al. 2018).

In the present study, the performances of Ti- and Zr-based coagulants for the treatment of real industrial wastewater were investigated and compared with traditional coagulants. The present study was conducted to achieve following five goals: (1) investigate and compare the coagulation performance of $\mathrm{TiCl}_{4}, \mathrm{ZrCl}_{4}, \mathrm{ZrOCl}_{2} \cdot 8 \mathrm{H}_{2} \mathrm{O}, \mathrm{Al}_{2}\left(\mathrm{SO}_{4}\right)_{3} \cdot 18 \mathrm{H}_{2} \mathrm{O}$, and $\mathrm{FeCl}_{3}$ for their COD and TSS removal efficiency from industrial wastewater obtained from an organized industrial-zone wastewater treatment plant; (2) determine the experimental conditions that deliver the optimum removal efficiency; (3) determine the sludge volume index (SVI) and the volume of settled sludge for each coagulant under optimum conditions; (4) determine the total phosphorus (TP), color, and metal removal efficiencies from the wastewater under the same optimum conditions; and (5) analyze the characteristics of the residual sludge obtained under optimum conditions.

\section{Materials and methods}

\section{Industrial wastewater}

Industrial wastewater was collected from an organized industrial-zone wastewater treatment plant located in Antalya, Turkey, that uses physical, chemical, and biological treatment processes. This plant collects wastewater from food, machinery, plastics, construction, wood, chemicals, textile, fertilizers, electrical, and electronics processes. The wastewater treatment plant has the capacity of $20,000 \mathrm{~m}^{3} /$ day and $\mathrm{FeCl}_{3}$ is the coagulant used in the chemical treatment phase. The wastewater was sampled from the equalization tank's effluent and was initiated just before the chemical treatment process began.

The industrial wastewater was characterized for content immediately after the sample arrived at the laboratory and the sample was refrigerated at $4{ }^{\circ} \mathrm{C}$.

The characteristics of the industrial wastewater are shown in Table 1. The COD, TSS, TP, and color content of this wastewater were high and contained $\mathrm{Fe}, \mathrm{Al}, \mathrm{Cu}$, and $\mathrm{Zn}$.

\section{Chemicals and coagulants}

The coagulants used in the jar test experiments were $\mathrm{Al}_{2}\left(\mathrm{SO}_{4}\right)_{3} \cdot 18 \mathrm{H}_{2} \mathrm{O}, \mathrm{FeCl}_{3}$, zirconium tetrachloride $\left(\mathrm{ZrCl}_{4}\right)$, titanium tetrachloride $\left(\mathrm{TiCl}_{4}\right)$ and $\mathrm{ZrOCl}_{2} \cdot 8 \mathrm{H}_{2} \mathrm{O}$. For flocculation, an anionic polyelectrolyte solution was used as the flocculant. The stock solutions of $\mathrm{Al}_{2}\left(\mathrm{SO}_{4}\right)_{3} \cdot 18 \mathrm{H}_{2} \mathrm{O}(98 \%$,

Table 1 Physical and chemical characteristics of the industrial wastewater used in this study

\begin{tabular}{lll}
\hline Parameter & Mean \pm standard deviation & Effluent standard $^{\text {a }}$ \\
\hline $\mathrm{TS}, \mathrm{mg} / \mathrm{L}$ & $4080 \pm 208.81$ & Not identified \\
$\mathrm{TSS}, \mathrm{mg} / \mathrm{L}$ & $1193.33 \pm 147.42$ & 200 \\
$\mathrm{COD}, \mathrm{mg} / \mathrm{L}$ & $3020 \pm 56.57$ & 400 \\
$\mathrm{TP}, \mathrm{mg} / \mathrm{L}$ & $15.24 \pm 0.04$ & 2 \\
$\mathrm{Color}, \mathrm{Pt}-\mathrm{Co}$ & $580 \pm 48$ & 280 \\
$\mathrm{pH}$ & 6.89 & $6-9$ \\
$\mathrm{SO}{ }_{4}{ }^{2-}, \mathrm{mg} / \mathrm{L}$ & $138.10 \pm 14$ & 1500 \\
$\mathrm{Fe}, \mathrm{mg} / \mathrm{L}$ & $0.24 \pm 0.00$ & 10 \\
$\mathrm{Al}, \mathrm{mg} / \mathrm{L}$ & $0.12 \pm 0.01$ & Not identified \\
$\mathrm{Cu}, \mathrm{mg} / \mathrm{L}$ & $0.56 \pm 0.02$ & 3 \\
$\mathrm{Zn}, \mathrm{mg} / \mathrm{L}$ & $1.36 \pm 0.03$ & 5 \\
$\mathrm{Cd}, \mathrm{mg} / \mathrm{L}$ & b.d. $^{\mathrm{b}}$ & 0.1 \\
$\mathrm{~Pb}, \mathrm{mg} / \mathrm{L}$ & b.d. $^{\text {b }}$ & 2 \\
$\mathrm{Cr}, \mathrm{mg} / \mathrm{L}$ & b.d. $^{\text {b }}$ & 0.5 \\
$\mathrm{Ni}, \mathrm{mg} / \mathrm{L}$ & b.d. $^{\text {b }}$ & Not identified \\
\hline
\end{tabular}

${ }^{\mathrm{a}}$ The Turkish Water Pollution Control Regulation (MEF 2004)

b b.d., below detection limit 
Acros Organics, Belgium), $\mathrm{FeCl}_{3}$ (>98\% Tekkim Chemicals, Turkey) $\mathrm{ZrCl}_{4}$ (99.99\%, Merck, France), $\mathrm{ZrOCl}_{2} \cdot 8 \mathrm{H}_{2} \mathrm{O}$ (98\%, Acros Organics, Belgium), and anionic polyelectrolyte (1858 U, SNF Floerger, France) were prepared separately by adding $1 \mathrm{~g}$ chemicals to $1 \mathrm{~L}$ distilled water. Stock solution of $\mathrm{TiCl}_{4}(>99.9 \%$, density $1.72 \mathrm{~g} / \mathrm{mL}$, Acros Organics, Belgium) was prepared as previously detailed (Hussain et al. 2014; Pushpalatha and Lokeshappa 2015; Aziz et al. 2018). Hydrochloric acid $(\mathrm{HCl})$ and sodium hydroxide $(\mathrm{NaOH})$ were used to adjust the $\mathrm{pH}$ of the solutions before the jar test to the predetermined levels and keep the $\mathrm{pH}$ constant during the coagulation process. A solution of $0.1 \mathrm{~N} \mathrm{HCl}$ was prepared by adding $4.15 \mathrm{~mL} \mathrm{HCl} \mathrm{(37 \% ,} \mathrm{Merck,} \mathrm{Germany)} \mathrm{to}$ $500 \mathrm{~mL}$ distilled water. For $0.1 \mathrm{~N} \mathrm{NaOH}$ solution, $2 \mathrm{~g} \mathrm{NaOH}$ (99\%, Merck, Germany) solid were weighed and later dissolved in $500 \mathrm{~mL}$ distilled water. Each solution was mixed thoroughly to obtain the homogenized solution.

\section{Coagulation-flocculation experiment}

Coagulation experiments were conducted in a $1000-\mathrm{mL}$ beaker using a jar testing device (Velp Scientifica, JLT6, Italy) at different coagulant dosages and different initial pHs. First, the industrial wastewater samples were removed from the refrigerator and allowed to reach ambient temperature. Second, the sample bottle was thoroughly agitated for resuspension of any possibly settled solids. Finally, $300 \mathrm{~mL}$ industrial wastewater was poured into a beaker. The coagulant was added to within the range of $10-100 \mathrm{mg} / \mathrm{L}$ to the sample, and the $\mathrm{pH}$ of the sample solution was adjusted to within the range of 4-10 by adding $0.1 \mathrm{~N} \mathrm{HCl}$ or $0.1 \mathrm{~N} \mathrm{NaOH}$. The operating parameters used were based on the literature reviewed. The solution was rapidly mixed at $200 \mathrm{rpm}$ for $5 \mathrm{~min}$, after which $5 \mathrm{mg} / \mathrm{L}$ flocculant was added followed by slow mixing at $20 \mathrm{rpm}$ for $30 \mathrm{~min}$. The flocs were allowed to settle for $1 \mathrm{~h}$. The treated wastewater samples were collected from $3 \mathrm{~cm}$ below the water surface for subsequent measurements. COD and TSS were measured in these collected treated samples. The removal efficiency of these parameters has been determined by calculating the percentage removal. The experimental conditions under which optimum removal efficiency was observed were determined.

\section{Sludge volume index}

Sludge volume index (SVI) was measured after determining the optimum $\mathrm{pH}$ and coagulant dose for the jar test using the sludge produced under optimum conditions. SVI is a measure of sludge settleability, which is often used in the biological processes with activated sludge; however, it is applicable for chemical sludge and considered to be an index by which to assess the ability to dewater the sludge and ease of handling (Taheriyoun et al. 2020). This test was conducted according to the standard methods (APHA 2005). The standard SVI test requires a 1-L graduated cylinder for the sludge settling test. SVI tests were conducted under conditions that produced the best treatment efficiencies for each coagulant in a 1000-mL sample volume. After adding the coagulant, both rapid and slow mixing were conducted in a jar test setup and the contents were transferred to a 1-L Imhoff cones and allowed to settle for $30 \mathrm{~min}$, after which the settled sludge volume was read. The settled sludge volume at the end of 60 min was also read.

\section{Analytical procedure}

The $\mathrm{pH}$, total solids (TS), total suspended solids (TSS), color, and sulfate ion $\left(\mathrm{SO}_{4}{ }^{2-}\right)$ were analyzed according to the procedure described in the Standard Methods (APHA 2005). Chemical oxygen demand (COD) was determined using the Hach reactor digestion method. The metals and total phosphorus (TP) contents were determined using inductively coupled plasma optical emission spectrometry (ICP-OES) (Perkin Elmer, DV2100) by filtering the wastewater sample through $0.45-\mu \mathrm{m}$ membrane filters.

Residual sludge produced from coagulation-flocculation under optimum test conditions was dewatered and dried at $103{ }^{\circ} \mathrm{C}$ for $12 \mathrm{~h}$, and the dried residual sludge samples were ground. The surface morphology and the chemical composition of the residual sludge were analyzed using a scanning electron microscope (SEM, FEI, Quanta FEG 250) equipped with an energy-dispersive spectroscopy (EDS). To analyze the metal and TP contents, 0.1 g sludge samples were weighed and digested in a microwave containing nitric acid $\left(\mathrm{HNO}_{3}\right)$ and $\mathrm{HCl}$. The metal and TP contents were measured using ICP-OES (Perkin Elmer, DV2100) after the acidic microwave digestion.

All experiments were replicated to assess the reproducibility of the results; the mean values are presented.

\section{Results and discussion}

\section{Coagulation performance of $\mathrm{Al}_{2}\left(\mathrm{SO}_{4}\right)_{3} \cdot 18 \mathrm{H}_{2} \mathrm{O}, \mathrm{FeCl}_{3}$, $\mathrm{ZrCl}_{4}, \mathrm{TiCl}_{4}$, and $\mathrm{ZrOCl}_{2} \cdot 8 \mathrm{H}_{2} \mathrm{O}$ for the treatment of industrial wastewater}

\section{Removal efficiencies for COD and TSS}

The treatment efficiencies obtained from five different coagulant doses and five different $\mathrm{pH}$ values for COD removal are illustrated in Fig. 1a-d. As seen from Fig. 1a, at $\mathrm{pH} 4,100 \mathrm{mg} / \mathrm{L}$ dose for all coagulants was the most efficient at COD removal. Under these conditions, the removal efficiencies from the highest to the lowest were $\mathrm{ZrCl}_{4}(67.20 \%)>\mathrm{FeCl}_{3}(66.66 \%)>\mathrm{ZrOCl}_{2}$ 

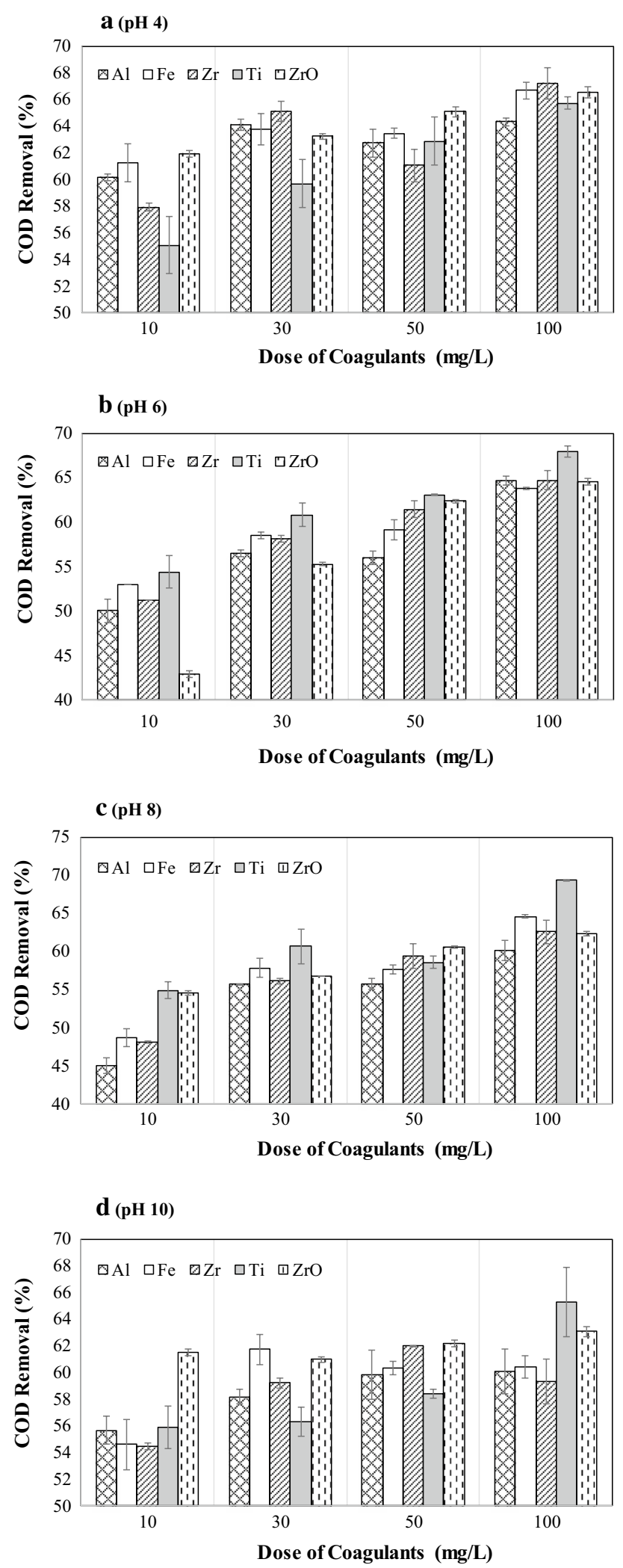

Fig. 1 Performance comparison of $\mathrm{Al}, \mathrm{Fe}, \mathrm{Zr}$, Ti, and $\mathrm{ZrO}$ coagulants in terms of COD removal efficiency at various doses at $\mathrm{pH} 4$ (a), 6 (b), 8 (c), and 10 (d)
$(66.54 \%)>\mathrm{TiCl}_{4}(65.71 \%)>\mathrm{Al}_{2}\left(\mathrm{SO}_{4}\right)_{3}(64.30 \%)($ Fig. 1a). At pH 6, the highest COD removal efficiency was $67.93 \%$ at $100 \mathrm{mg} / \mathrm{L}$ of $\mathrm{TiCl}_{4}$ dose and the lowest removal efficiency was $42.84 \%$ at $10 \mathrm{mg} / \mathrm{L}$ of $\mathrm{ZrOCl}_{2}$ dose (Fig. 1b). At $\mathrm{pH} 8$, the highest COD removal efficiency was $69.33 \%$ at $100 \mathrm{mg} / \mathrm{L}$ of $\mathrm{TiCl}_{4}$ dose, and the lowest removal efficiency was $44.96 \%$ at $10 \mathrm{mg} / \mathrm{L}$ of $\mathrm{Al}_{2}\left(\mathrm{SO}_{4}\right)_{3}$ dose (Fig. 1c). At $\mathrm{pH} 10$, the highest COD removal efficiency was $65.25 \%$ at $100 \mathrm{mg} / \mathrm{L}$ of $\mathrm{TiCl}_{4}$ dose and the lowest removal efficiency was $54.43 \%$ at $10 \mathrm{mg} / \mathrm{L}$ of $\mathrm{ZrCl}_{4}$ dose (Fig. 1d).

The lowest dose examined in the study was $10 \mathrm{mg} / \mathrm{L}$. At both pH 6 and 8, the COD removal efficiencies with this dose were below $55 \%$ for all coagulants. For all of the coagulants tested, the best COD removal efficiencies were achieved at $100 \mathrm{mg} / \mathrm{L}$ of coagulant dose. The highest COD removal efficiencies for $\mathrm{ZrCl}_{4}, \mathrm{FeCl}_{3}$, and $\mathrm{ZrOCl}_{2}$ were $67.20 \%, 66.66 \%$, and $66.54 \%$ at a dose of $100 \mathrm{mg} / \mathrm{L}$ and at $\mathrm{pH} 4$, respectively. However, for $\mathrm{TiCl}_{4}$, the highest removal efficiency was $69.33 \%$ at a dose of $100 \mathrm{mg} / \mathrm{L}$ and at $\mathrm{pH} 8$. At a dose of $100 \mathrm{mg} / \mathrm{L}$, the highest COD removal efficiency for $\mathrm{AlSO}_{4}$ was $64.30 \%$ at pH 6 and $64.66 \%$ at pH 8 (Fig. 1a-d).

The $\mathrm{pH}$ of the coagulation depends on the coagulant type and the wastewater to be treated. Except for $\mathrm{TiCl}_{4}$ the highest COD removal efficiencies were observed at $\mathrm{pH} 4$. However, for $\mathrm{TiCl}_{4}$, the highest removal efficiency was at pH 8. Similarly, Zhao et al. (2011b) have reported that the highest COD and dissolved organic carbon (DOC) removal efficiencies in surface water treatment were observed with $\mathrm{TiCl}_{4}$ at $\mathrm{pH}$ 8. In acidic conditions, hydrolysis of $\mathrm{TiCl}_{4}$ may be restrained, while Al- and Fe-salt coagulants are seldom affected (Zhao et al. 2011a). However, at a higher pH, $\mathrm{TiCl}_{4}$ coagulant is gradually hydrolyzed, resulting in better COD removal. $\mathrm{ZrCl}_{4}$ and $\mathrm{ZrOCl}_{2}$ performed best at a low $\mathrm{pH}$, which indicated that $\mathrm{Zr}$ polymeric cationic species are most prominent at this pH (Hussain et al. 2014). Similarly, Jarvis et al. (2012) have suggested a significant role of highly charged cationic hydrolysis species produced when $\mathrm{ZrOCl}_{2} \cdot 8 \mathrm{H}_{2} \mathrm{O}$ is dissolved in water.

The TSS removal efficiencies from industrial wastewater using five different coagulant doses and five different $\mathrm{pH}$ values are shown in Fig. 2a-d. At pH 4, the highest TSS removal efficiencies were $92.46 \%$ at $30 \mathrm{mg} / \mathrm{L}$ of $\mathrm{Al}_{2}\left(\mathrm{SO}_{4}\right)_{3}$ dose and $92.21 \%$ at $100 \mathrm{mg} / \mathrm{L}$ of $\mathrm{Al}_{2}\left(\mathrm{SO}_{4}\right)_{3}$ dose. The lowest TSS removal efficiency was $61.04 \%$ at $10 \mathrm{mg} / \mathrm{L}$ of $\mathrm{Al}_{2}\left(\mathrm{SO}_{4}\right)_{3}$ dose and at $\mathrm{pH} 4$ (Fig. 2a). At pH 6, the highest TSS removal efficiency observed was $94.13 \%$ at $30 \mathrm{mg} / \mathrm{L}$ of $\mathrm{Al}_{2}\left(\mathrm{SO}_{4}\right)_{3}$ dose, whereas the lowest was $49.17 \%$ at $10 \mathrm{mg} / \mathrm{L}$ of $\mathrm{ZrOCl}_{2}$ dose (Fig. 2b). At pH $8,50 \mathrm{mg} / \mathrm{L} \mathrm{Al}_{2}\left(\mathrm{SO}_{4}\right)_{3}$ dose produced the highest TSS removal efficiency of $98.32 \%$, and $10 \mathrm{mg} / \mathrm{L} \mathrm{Al}{ }_{2}\left(\mathrm{SO}_{4}\right)_{3}$ dose produced the lowest TSS removal efficiency of $57.14 \%$ (Fig. 2c). At pH 10, except for $\mathrm{TiCl}_{4}$, the highest removal efficiencies were achieved at $50 \mathrm{mg} / \mathrm{L}$ 

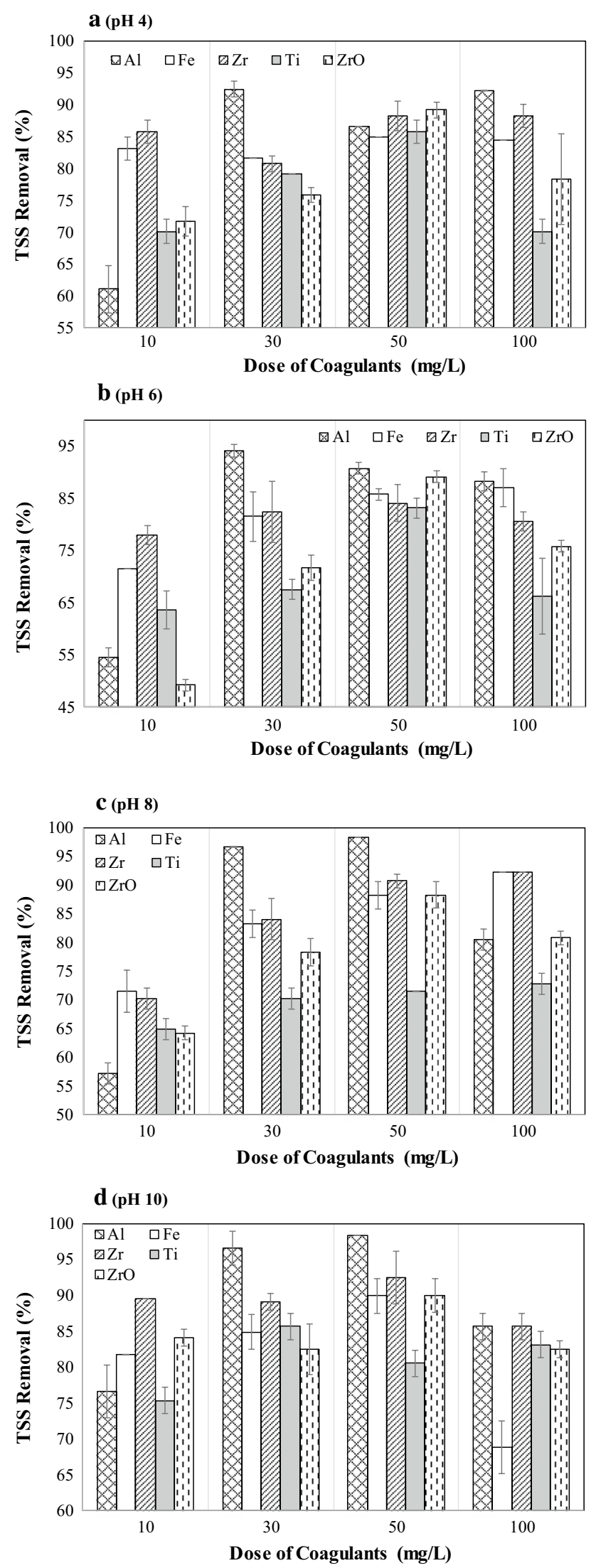

Fig. 2 Performance comparison of $\mathrm{Al}, \mathrm{Fe}, \mathrm{Zr}$, $\mathrm{Ti}$, and $\mathrm{ZrO}$ coagulants in terms of TSS removal efficiency at various doses at pH $4(\mathbf{a}), 6(\mathbf{b}), 8(\mathbf{c})$, and 10 (d)

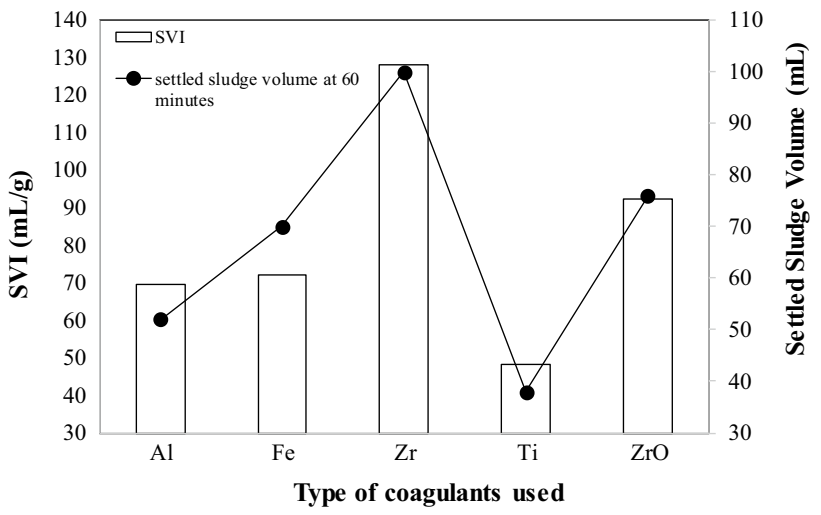

Fig. 3 Sludge volume index $\left(\mathrm{SVI}_{30}=30 \mathrm{~min}\right.$ of settling time $)$ and settled sludge volume at 60 min against each coagulant used

of each coagulant dose with $\mathrm{Al}_{2}\left(\mathrm{SO}_{4}\right)_{3}(98.32 \%)>\mathrm{ZrCl}_{4}$ $(92.46 \%)>\mathrm{ZrOCl}_{2}(90.00 \%)>\mathrm{FeCl}_{3}$ (89.94\%) (Fig. 2d).

\section{Determination of settled sludge volume, SVI, and removal efficiency rates of metals, color, and TP under the optimum conditions}

To reduce the load on biological treatment processes, it was very common to use coagulation-flocculation processes as a pretreatment method in wastewater treatment plants within organized industrial zones. The present study's wastewater treatment plant in the organized industrial zone also contains a coagulation-flocculation pretreatment process initiated just before biological treatment.

To be able to reduce the load on biological treatment, decreasing the COD concentration of wastewater with a chemical treatment step is critical, which is why this study considered COD instead of TSS removal efficiencies while determining the optimum conditions.

The best COD removal efficiencies for $\mathrm{FeCl}_{3}, \mathrm{ZrCl}_{4}$, and $\mathrm{ZrOCl}_{2}$ were obtained at $\mathrm{pH} 4$ and at a dose of $100 \mathrm{mg} / \mathrm{L}$, whereas for $\mathrm{TiCl}_{4}$, this occurred at $\mathrm{pH} 8$ and a dose of $100 \mathrm{mg} / \mathrm{L}$. For $\mathrm{Al}_{2}\left(\mathrm{SO}_{4}\right)_{3}$, the best COD removal efficiencies were very similar at $\mathrm{pH} 4$ and 6 , with $64.30 \%$ and $64.66 \%$, respectively. Then, because TSS removal with the same coagulant was most efficient at $92.21 \%$ at $\mathrm{pH} 4$, that $\mathrm{pH}$ was recorded as the optimum condition for $\mathrm{Al}_{2}\left(\mathrm{SO}_{4}\right)_{3}$.

The five different coagulants had similar COD removal efficiencies. The best efficiency ranges obtained from these coagulants under their respective optimum conditions were between 64.30 and $69.33 \%$. Similarly, Shon et al. (2007) have reported that $\mathrm{Al}_{2}\left(\mathrm{SO}_{4}\right)_{3}, \mathrm{FeCl}_{3}$, and $\mathrm{TiCl}_{4}$ used to remove organic matter from synthetic wastewater resulted in similar removal efficiencies among all of them.

SVI was identified in this study for $\mathrm{Al}_{2}\left(\mathrm{SO}_{4}\right)_{3}, \mathrm{FeCl}_{3}$, $\mathrm{ZrCl}_{4}, \mathrm{TiCl}_{4}$, and $\mathrm{ZrOCl}_{2}$ under optimum conditions and $30 \mathrm{~min}$ of settling time (i.e., $\mathrm{SVI}_{30}$ ). Figure 3 shows the 
obtained $\mathrm{SVI}_{30}$ values and settled sludge volumes $60 \mathrm{~min}$ after the coagulation processes were measured under optimum conditions. A lower value of SVI indicates a good settling sludge, which has a bigger floc size and requires a shorter time for the sedimentation process (Bhatia et al. 2007; Zainol et al. 2019). $\mathrm{TiCl}_{4}$ produced a lower SVI compared to the other coagulants used (Fig. 3) and is more capable of producing compact sludge at a lower settling time than the other coagulants. Settled sludge volume after $60 \mathrm{~min}$ was also lowest in $\mathrm{TiCl}_{4}$ (Fig. 3). Based on these results, using $\mathrm{TiCl}_{4}$ will have more of an advantage in sludge operations at the treatment plant and will produce less sludge at the final discharge point. This will make is easier for the sludge conductor to dispose of the sludge.

Figure 4 illustrates the removal efficiencies of $\mathrm{TP}, \mathrm{Cu}$, $\mathrm{Zn}$, and color using five different coagulants applied under optimum conditions. In addition to COD and TSS, industrial wastewater has high TP and color strength (Table 1). With $\mathrm{TiCl}_{4}$ and $\mathrm{ZrOCl}_{2}$, TP removal efficiencies were $>93.7 \%$ (Fig. 4). With $\mathrm{ZrCl}_{4}, \mathrm{TiCl}_{4}$, and $\mathrm{ZrOCl}_{2}$, it was observed that the effluent standard in the regulation was met with regard to TP content (Table 1). Thus, with $\mathrm{ZrCl}_{4}, \mathrm{TiCl}_{4}$, and $\mathrm{ZrOCl}_{2}$ were sufficient for removing TP without needing further treatment. The removal efficiencies for $\mathrm{Cu}$ and $\mathrm{Zn}$ removal were better in $\mathrm{Ti}$ and $\mathrm{Zr}$ salt applications than the traditional coagulants performance (Fig. 4). Similarly, Galloux et al. (2015) have reported that the Ti-based coagulants had higher removal efficiency for multivalent metal than $\mathrm{FeCl}_{3}$. Color removal efficiency rates $>82.5 \%$ were obtained with $\mathrm{Al}_{2}\left(\mathrm{SO}_{4}\right)_{3}, \mathrm{ZrCl}_{4}$, and $\mathrm{ZrOCl}_{2}$ (Fig. 4).

\section{Characterization of residual sludge produced from coagulation-flocculation under optimum conditions}

The morphology and the chemical composition of the residual sludge were analyzed using SEM-EDS analysis of the sludge after coagulation-flocculation process using all coagulants at the optimum test conditions. The sludge surface morphology was analyzed by SEM, while the containing ions were analyzed by EDX.

Figure 5a-e presents the SEM images of the residual sludge produced for all five tested coagulants under optimum conditions. SEM images generally represent the physical morphology of the particles. From these figures, it is clear that the flocs produced after the coagulation-flocculation process are hard and compact because colloidal particles entrapped in these flocs. SEM images showed that residual sludges were heterogeneous mixtures of particles with irregular shape and variable sizes with concentration of particle size at around $30 \mu \mathrm{m}$ (Fig. 5a-e).

The EDS spectra of the residual sludges are shown in Fig. 6a-e. EDS analysis shows that $\mathrm{C}, \mathrm{P}, \mathrm{Al}$, and $\mathrm{Ca}$ are the most abundant elements, whereas $\mathrm{Si}$ and $\mathrm{S}$ are detected at relatively low concentrations (Fig. 6a-e). The percentage of $\mathrm{C}$ on the floc surfaces is high which indicates that organic compounds are removed during the coagulation-flocculation process. The EDS results evidence that the coagulation-flocculation process using all five tested coagulants does not only remove dissolved organic matter, but also traps other pollutants from the industrial wastewater inside the flocs, due to the adsorption or through complexation process.

The TP and metal contents in the residual sludge produced for all five tested coagulants under optimum conditions are provided in Table 2. A very high concentration of TP was observed in the residual sludge when $\mathrm{Ti}$ and $\mathrm{Zr}$ salt-based coagulants were used in the process.

Recovery processes can be applied to recycle TP from the residual sludge obtained after the coagulation-flocculation procedure. Using the chemical extraction method, the $\mathrm{P}$ content of the residual sludge can be transformed into the liquid phase, and an ion-exchange membrane can recover the liquid-phase P (Uysal et al. 2017).
Fig. 4 Removal efficiencies for $\mathrm{TP}, \mathrm{Cu}, \mathrm{Zn}$, and color in wastewater for all five tested coagulants under optimum conditions

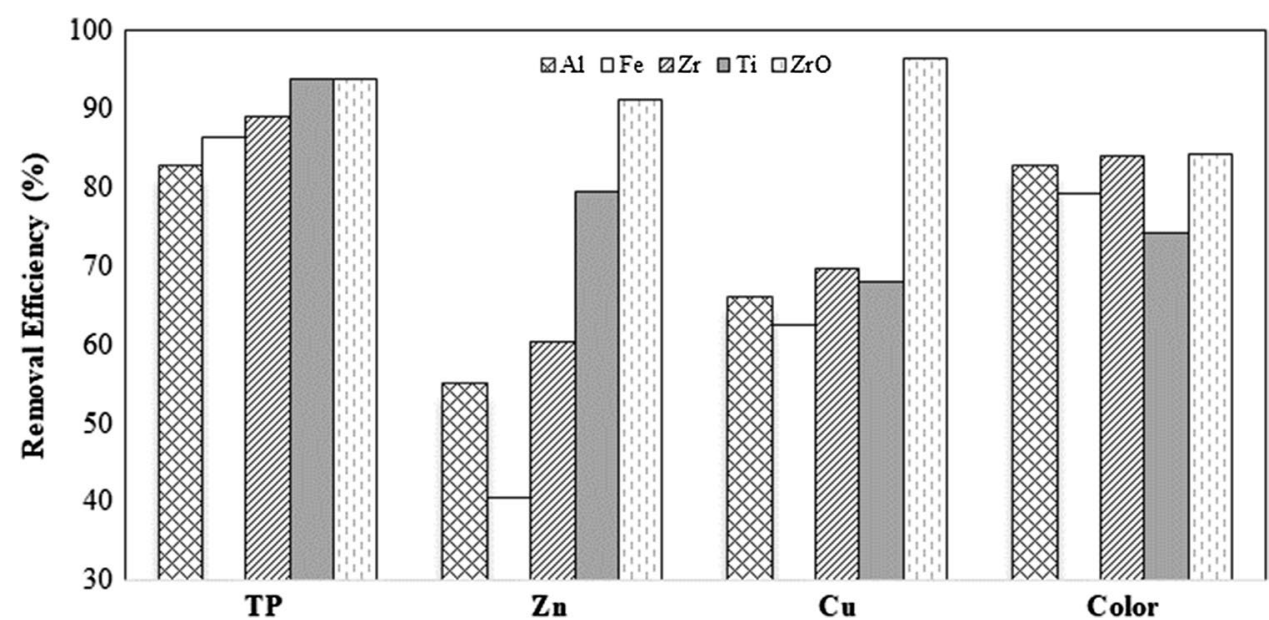

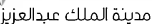
KACST Ka 
$\mathbf{a}\left(\mathrm{TiCl}_{4}\right)$

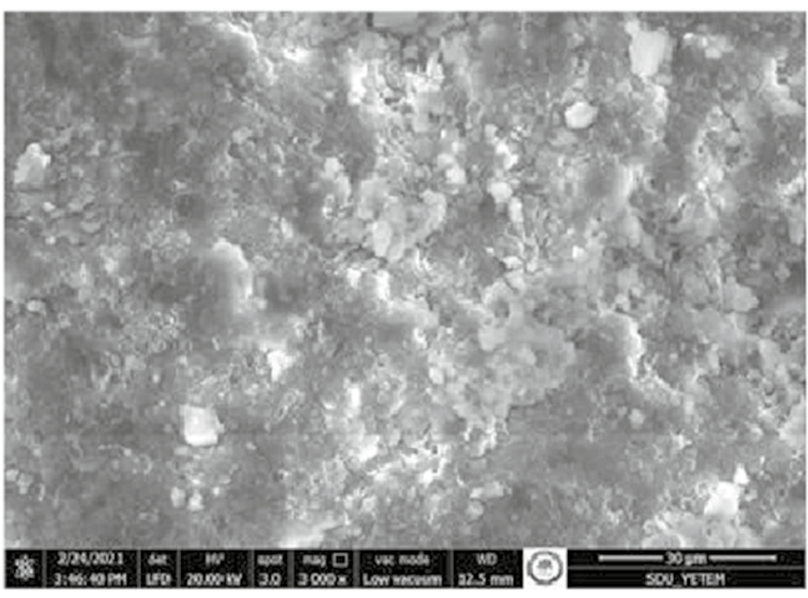

$\mathrm{c}\left(\mathrm{ZrOCl}_{2}\right)$

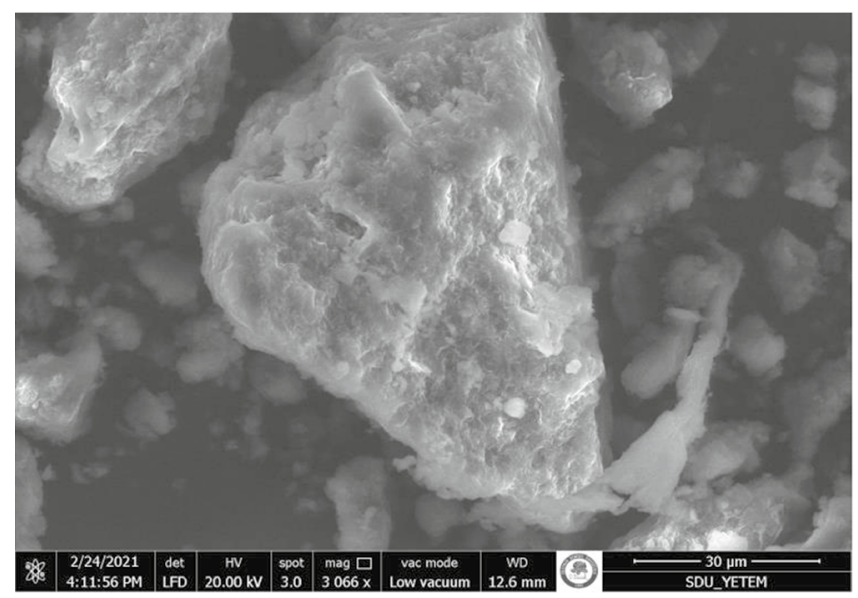

e $\left(\mathrm{FeCl}_{3}\right)$

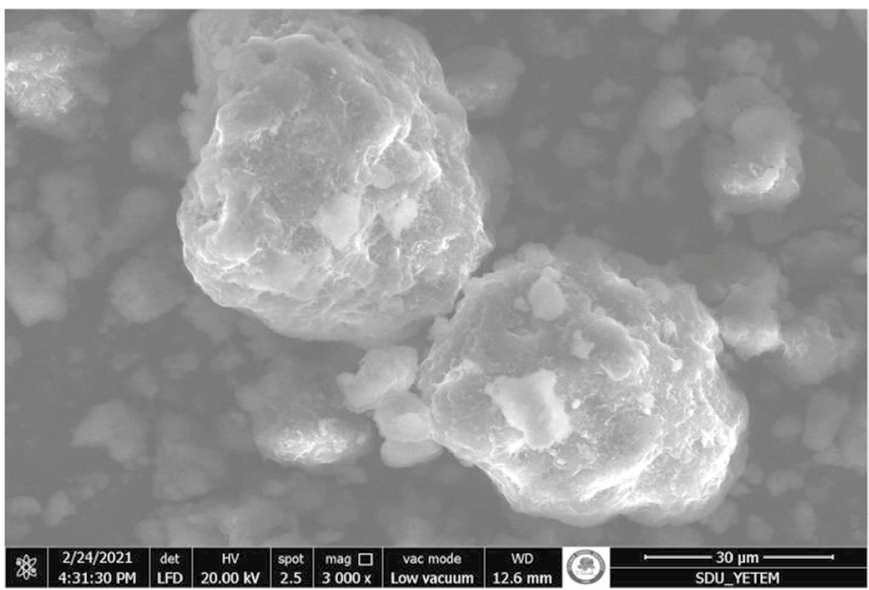

Fig. 5 SEM images of $\mathrm{TiCl}_{4}$ sludge (a), $\mathrm{ZrCl}_{4}$ sludge (b), $\mathrm{ZrOCl}_{2}$ sludge (c), $\mathrm{Al}_{2}\left(\mathrm{SO}_{4}\right)_{3}$ sludge $(\mathbf{d})$, and $\mathrm{FeCl}_{3}$ sludge (e) at magnification $3000 \mathrm{x}$

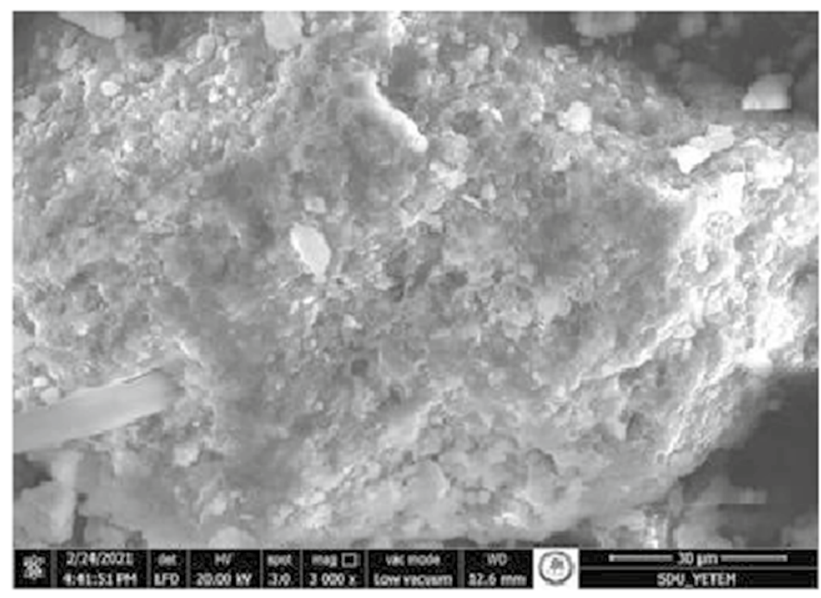

$\mathrm{d}\left(\mathrm{Al}(\mathrm{SO})_{4}\right)_{3}$

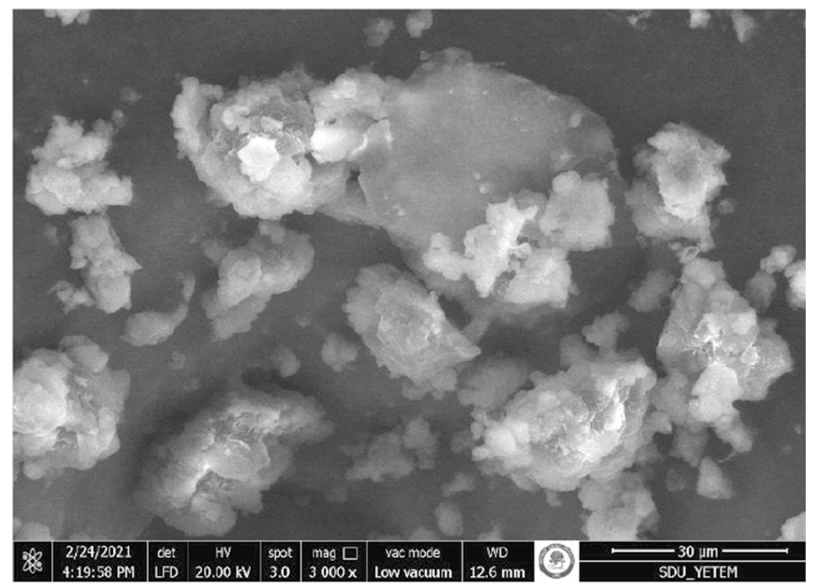


a $\left(\mathrm{TiCl}_{4}\right)$

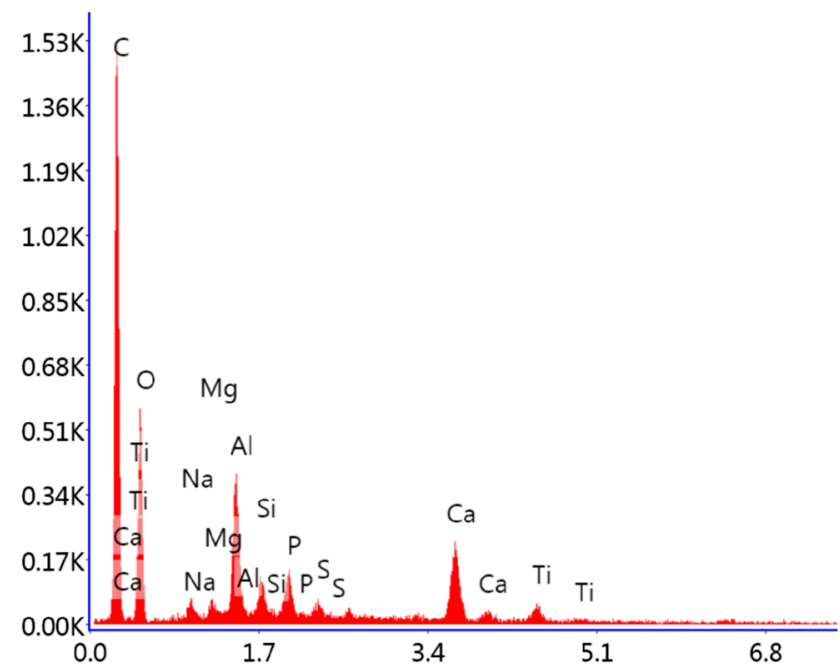

c $\left(\mathrm{ZrOCl}_{2}\right)$

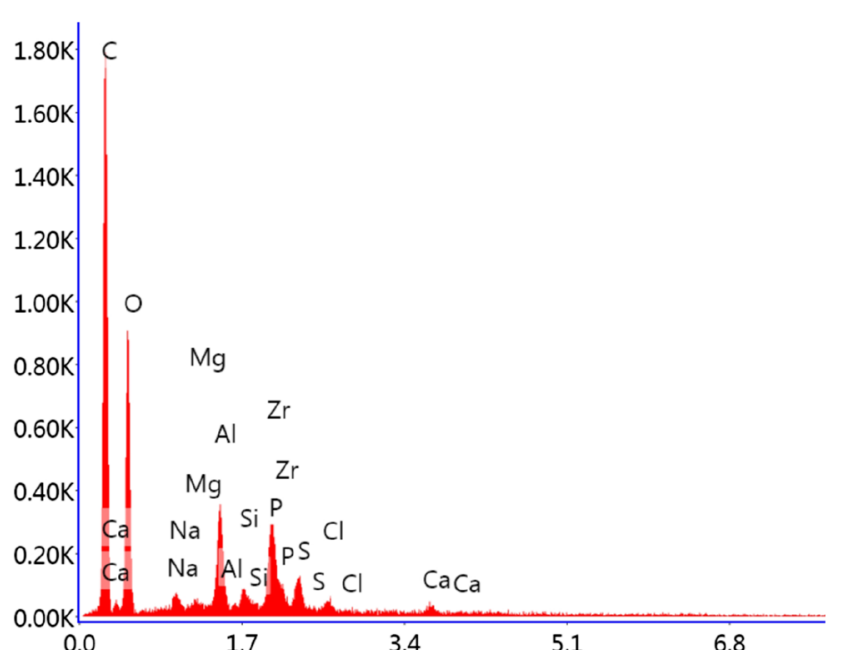

e $\left(\mathrm{FeCl}_{3}\right)$

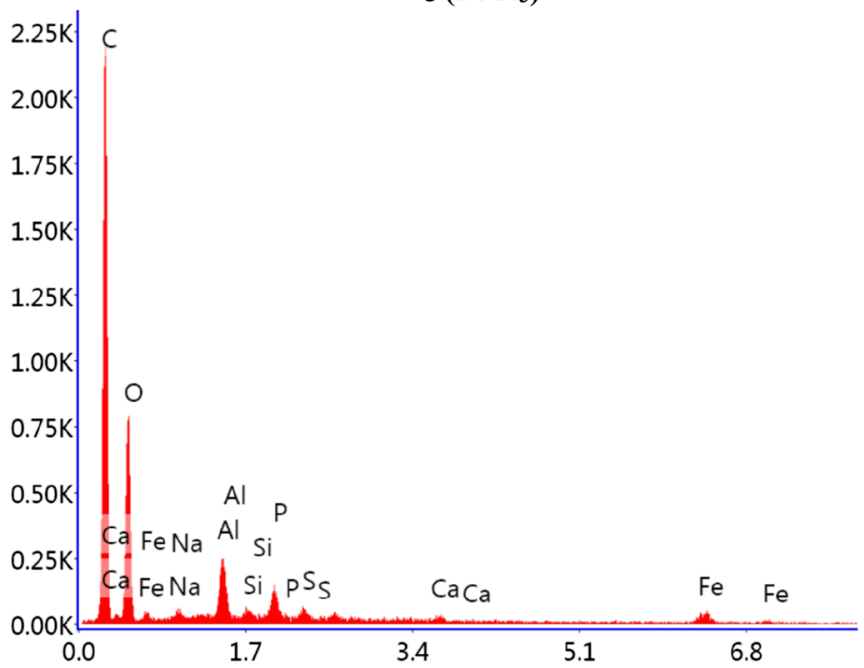

$\mathbf{b}\left(\mathrm{ZrCl}_{4}\right)$
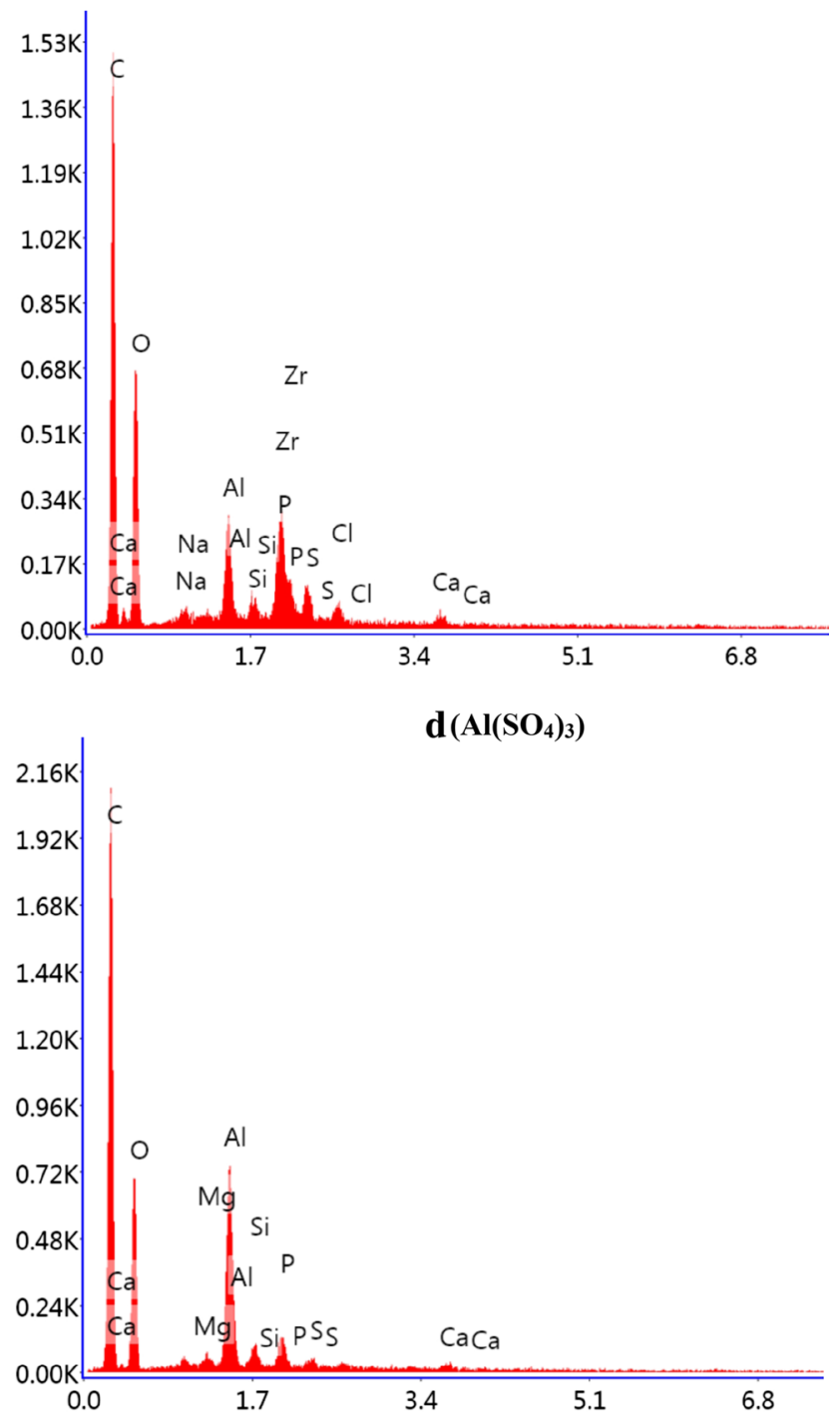

Fig. 6 Energy-dispersive spectra of $\mathrm{TiCl}_{4}$ sludge (a), $\mathrm{ZrCl}_{4}$ sludge (b), $\mathrm{ZrOCl}_{2}$ sludge (c), $\mathrm{Al}_{2}\left(\mathrm{SO}_{4}\right)_{3}$ sludge (d), and $\mathrm{FeCl}_{3}$ sludge (e) 
Table 2 Characterization of residual sludge produced for all five tested coagulants under optimum conditions

\begin{tabular}{lcllc}
\hline Coagulants & TP $(\mathrm{mg} / \mathrm{kg})$ & $\mathrm{Zn}(\mathrm{mg} / \mathrm{kg})$ & $\mathrm{Cu}(\mathrm{mg} / \mathrm{kg})$ & $\mathrm{Fe}(\mathrm{mg} / \mathrm{kg})$ \\
\hline $\mathrm{TiCl}_{4}$ & 5390 & 4194 & 147.6 & 1497 \\
$\mathrm{ZrCl}_{4}$ & 4893 & 3153 & 149.7 & 2279 \\
$\mathrm{ZrOCl}_{2}$ & 5269 & 4006 & 153.0 & 2069 \\
$\mathrm{Al}_{2}\left(\mathrm{SO}_{4}\right)_{3}$ & 898 & 3330 & 128.9 & 1763 \\
$\mathrm{FeCl}_{3}$ & 1929 & 2781 & 124.7 & 16,540 \\
\hline
\end{tabular}

\section{Conclusion}

The performances of Ti- and $\mathrm{Zr}$-based coagulants were assessed and compared with that of traditional $\mathrm{FeCl}_{3}$ and $\mathrm{Al}_{2}\left(\mathrm{SO}_{4}\right)_{3}$ for the treatment of real industrial wastewater. Coagulation performances were evaluated in terms of pollutant removal (COD, TSS, TP, metals, and color) and sludge settleability. The results showed that Ti- and Zr-based coagulants produced COD removal efficiencies nearly similar to that of $\mathrm{FeCl}_{3}$ and $\mathrm{Al}_{2}\left(\mathrm{SO}_{4}\right)_{3}$. The maximum removal efficiency of COD (69.33\%) was observed using $100 \mathrm{mg} / \mathrm{L}$ $\mathrm{TiCl}_{4}$, at $\mathrm{pH} 8$. For the other coagulants, the best removal efficiency of COD was observed at $\mathrm{pH} 4$. The $\mathrm{pH} 8$ optimum value for $\mathrm{TiCl}_{4}$ is very advantageous because immediately after the chemical treatment, there is a biological treatment phase, which, in this case, the $\mathrm{pH}$ if would not need to be adjusted. $\mathrm{TiCl}_{4}, \mathrm{ZrCl}_{4}$, and $\mathrm{ZrOCl}_{2}$ performed better than $\mathrm{FeCl}_{3}$ and $\mathrm{Al}_{2}\left(\mathrm{SO}_{4}\right)_{3}$ in terms of $\mathrm{TP}, \mathrm{Cu}$, and $\mathrm{Zn}$ removal. With $\mathrm{TiCl}_{4}$ and $\mathrm{ZrOCl}_{2}$, TP removal efficiencies over $93.7 \%$ were obtained. $\mathrm{ZrCl}_{4}$ and $\mathrm{ZrOCl}_{2}$ had higher efficient rates for color removal than $\mathrm{TiCl}_{4}, \mathrm{FeCl}_{3}$, and $\mathrm{Al}_{2}\left(\mathrm{SO}_{4}\right)_{3}$. In addition, the SVI test showed that $\mathrm{TiCl}_{4}$ generated less sludge compared to other coagulants used. Where the SVI of $\mathrm{TiCl}_{4}$ was $48.84 \mathrm{~mL} / \mathrm{g}$, while it was 72.26 and $69.66 \mathrm{~mL} / \mathrm{g}$ for the $\mathrm{FeCl}_{3}$ and $\mathrm{Al}_{2}\left(\mathrm{SO}_{4}\right)$ under optimum conditions. The EDS analysis of the residual sludges exhibits that the high content of $\mathrm{C}$ was obtained with the use of all tested coagulants. The other principal chemical components were $\mathrm{Al}$ and $\mathrm{P}$. The residual sludge obtained when $\mathrm{Ti}$ and $\mathrm{Zr}$ salt-based coagulants were used had elevated TP. Because natural P resources throughout the world are severely limited, sewage sludge is an important resource for P recovery, and when using various extraction techniques, $\mathrm{P}$ recovery from this residual sludge might be realized. Ti- and Zi-based coagulants can be used in further practices, such as landfill leachate, tannery wastewater, textile wastewater, that contain high levels of organic compounds, suspended solids, and heavy metals.

Funding This work was supported by the Research Project Funding Unit of Suleyman Demirel University (Project No. 5091-YL1-17).

\section{Declarations}

Conflict of interest The authors declare that they have no conflict of interest.

Open Access This article is licensed under a Creative Commons Attribution 4.0 International License, which permits use, sharing, adaptation, distribution and reproduction in any medium or format, as long as you give appropriate credit to the original author(s) and the source, provide a link to the Creative Commons licence, and indicate if changes were made. The images or other third party material in this article are included in the article's Creative Commons licence, unless indicated otherwise in a credit line to the material. If material is not included in the article's Creative Commons licence and your intended use is not permitted by statutory regulation or exceeds the permitted use, you will need to obtain permission directly from the copyright holder. To view a copy of this licence, visit http://creativecommons.org/licenses/by/4.0/.

\section{References}

APHA, AWWA, WEF (2005) Standard methods for the examination of water and wastewater, 21st ed. Washington, DC

Aziz HA, Razak MHA, Rahim MZA, Kamar WISW, Amr SSA, Hussain S, Leeuwen JV (2018) Evaluation and comparison the performance of titanium and zirconium(IV) tetrachloride in textile wastewater. Data Brief 18:920-927

Bhatia S, Othman Z, Ahmad AL (2007) Pretreatment of palm oil mill effluent (POME) using moringa oleifera seeds as natural coagulant. J Hazard Mater 145(1):120-126

Galloux J, Chekli L, Phuntsho S, Tijing LD, Jeong S, Zhao YX, Gao BY, Park SH, Shon HK (2015) Coagulation performance and floc characteristics of polytitanium tetrachloride and titanium tetrachloride compared with ferric chloride for coal mining wastewater treatment. Sep Purif Technol 152:94-100

Hussain S, Leeuwen JV, Chow CWK, Aryal R, Beecham S, Duan J, Drikas M (2014) Comparison of the coagulation performance of tetravalent titanium and zirconium salts with alum. Chem Eng J 254:635-646

Jarvis P, Jefferson B, Parsons SA (2005) Breakage, regrowth, and fractal nature of natural organic matter flocs. Environ Sci Technol 39(7):2307-2314

Jarvis P, Sharp E, Pidou M, Molinder R, Parsons SA, Jefferson B (2012) Comparison of coagulation performance and floc properties using a novel zirconium coagulant against traditional ferric and alum coagulants. Water Res 46:4179-4187

Ministry of Environmental and Forestry (MEF) (2004) The Turkish water pollution control regulation. Official Gazette no: 25687

Okour Y, Shon HK, Saliby IE (2009) Characterisation of titanium tetrachloride and titanium sulfate flocculation in wastewater treatment. Water Sci Technol 59(12):2463-2473

Okour YH, Ahmed SS (2019) An effective method of wastewater treatment using titanium salt and a coagulant aid of chitosan. Water Environ J 33(3):418-426

Priya T, Mohanta VL, Mishra BK (2017) Performance evaluation of zirconium oxychloride for reduction of hydrophobic fractions of natural organic matter. Sep Purif Technol 174:104-108

Pushpalatha TN, Lokeshappa B (2015) The use of alum, ferric chloride and titanium tetrachloride as coagulants in treating landfill leachate. Int J Sci Eng Technol Res 4(6):2093-2096

Shon HK, Vigneswaran S, Kim IS, Cho J, Kim GJ, Kim JB, Kim JH (2007) Preparation of titanium dioxide $\left(\mathrm{TiO}_{2}\right)$ from sludge produced by titanium tetrachloride $\left(\mathrm{TiCl}_{4}\right)$ flocculation of wastewater. Environ Sci Tech 41:1372-1377 
Syafalni S, Lim HK, Ismail N, Abustan I, Murshed MF, Ahmad A (2012) Treatment of landfill leachate by using lateritic soil as a natural coagulant. J Environ Manag 112:353-359

Taheriyoun M, Memaripour A, Nazari-Sharabian M (2020) Using recycled chemical sludge as a coagulant aid in chemical wastewater treatment in mobarakeh steel complex. J Mater Cycles Waste Manag 22:745-756

Tatsi AA, Zouboulis AI, Matis KA, Samaras P (2003) Coagulationflocculation pretreatment of sanitary landfill leachates. Chemosphere 53:737-744

Uysal A, Tuncer D, Kir E, Sardohan Köseoğlu T (2017) Recovery of nutrients from digested sludge as struvite with a combination process of acid hydrolysis and donnan dialysis. Water Sci Technol 76(10):2733-2741

Wu YF, Liu W, Gao NY, Tao T (2011) A study of titanium sulfate flocculation for water treatment. Water Res 45:3704-3711

Zainol NA, Mohamad NAN, Ghani A, Mahyun AW, Lutpi NA, Saad FNM (2019) Use of alum and ferric sulphate for treating landfill leachate via coagulation process: a comparative study. J Eng Res Educ 11:35-44

Zhao YX, Gao BY, Shon HK, Cao BC, Kim JH (2011a) Coagulation characteristics of titanium (Ti) salt coagulant compared with aluminum (Al) and iron (Fe) salts. J Hazard Mater 185:1536-1542

Zhao YX, Gao BY, Cao BC, Yang ZL, Yue QY, Shon HK, Kim JH (2011b) Comparison of coagulation behavior and floc characteristics of titanium tetrachloride $\left(\mathrm{TiCl}_{4}\right)$ and polyaluminum chloride (PACl) with surface water treatment. Chem Eng J 166(2):544-550

Publisher's note Springer Nature remains neutral with regard to jurisdictional claims in published maps and institutional affiliations. 